\title{
CORRELATION BETWEEN PROLONGED STANDING AND PLANTAR FASCIITIS
}

\author{
Ni Ketut Maya Purvitagiri ${ }^{1 *}$, Linda Dewanti ${ }^{2}$, Sulis Bayusentono ${ }^{3}$, Indrayuni Lukitra \\ Wardhani $^{4}$ \\ ${ }^{1}$ Forth year student, Faculty of Medicine, Airlangga University \\ ${ }^{2}$ Department of community medicine, Faculty of Medicine, Airlangga University \\ ${ }^{3}$ Department of Orthopaedic and Traumatology, Faculty of Medicine, Airlangga University, \\ Dr. Soetomo Hospital, Surabaya \\ ${ }^{4}$ Department of Medical Rehabilitation, Faculty of Medicine, Airlangga University, Dr. \\ Soetomo Hospital, Surabaya \\ *Correspondence: Ni Ketut Maya, Forth Year Medical Student, Faculty of Medicine, \\ Airlangga University, J1. Mayjen Prof. Dr. Moestopo No. 47 Surabaya 60131. \\ Email : mayapurvita@gmail.com
}

\begin{abstract}
ABSTRAK
Latar belakang: Plantar fasciitis (PF) adalah salah satu penyakit telapak kaki yang paling sering menyerang orang dewasa. Diperkirakan bahwa penyakit ini menyerang $10 \%$ populasi orang dewasa semasa hidupnya. Beberapa studi sebelumnya menyatakan bahwa berdiri yang berkepanjangan merupakan salah satu resiko penyebab PF, namun banyak studi lain yang membantah hal tersebut. Studi ini dibuat bertujuan untuk mencari tahu apakah berdiri yang berkepanjangan dapat menyebabkan PF. Metode: Studi ini berbentuk cross-sectional yang menggunakan total sampling dan melibatkan 73 pegawai pabrik. 35 dari subyek tidak memenuhi kriteria inklusi, maka dari itu hanya 38 subyek yand digunakan. Data dikumpulkan menggunakan Chi-square dengan nilai $\mathrm{p}<0.05$ dan confidence interval (CI) 95\%. Hasil: Tidak ada korelasi antara berdiri yang berkepanjangan dengan plantar fasciitis, $\mathrm{p}=0.249$. Kesimpulan: Tidak ada korelasi antara berdiri berkepanjangan dengan plantar fasciitis, dan walaupun beberapa studi sebelumnya menyatakan bahwa Body Mass Index, dan umur juga dapat menjadi salah satu faktor resiko, hal ini tidak dibuktikan di studi ini. Penelitian selanjutnya dapat menggunakan jumlah subyek yang lebih banyak dan menggunakan metode lain untuk mendefenisikan berdiri yang berkepanjangan.

Kata kunci : berdiri berkepanjangan, plantar fasciitis, penyakit telapak kaki
\end{abstract}

\begin{abstract}
Background: Plantar fasciitis (PF) is the most common heel pain in adult. It is estimated that it affects as much as $10 \%$ of the population over the course of their lifetime. Previous study mention that prolonged standing is one of the risk factor of PF, however other study suggests that there is low evidence of prolonged standing may cause PF. The objective of this study was to findout whether or not prolonged standing may correlate to PF. Methods: This crosssectional with total sampling study involved 73 workers in total. 35 of them did not fulfill the inclusion criteria, hence only 38 of subjects were used. The data collected using questionnare and analyzed using Chi-square. with p-value (p) $<0.05$ and confidence interval (CI) 95\%. Results: There is no correlation between prolonged standing and PF symptoms $\mathrm{p}=0.249$. Conclusion: There is no correlation between prolonged standing and plantar fasciitis and even though in other study suggest that BMI, and age also the risk factor of PF this was not
\end{abstract}


http://journalunair.ac.id/journal-of-orthopaedic-and-traumatology-surabaya-media-104.html

consistently confirmed in this study. Further research may use larger number of subjects and use other measure to determine the definition of prolonged standing.

Keywords: prolonged standing, plantar fasciitis, heel pain

\section{INTRODUCTION}

Plantar fasciitis (PF) is the most common heel pain in adult. The classic sign of $\mathrm{PF}$ is that the worst pain occurs with the first few step in the morning or at the beginning of the activity that lessen as they warm up. PF is a self-limiting disease, this means that it can heal by itself, however the resolution can take a long time up to $6-18$ months and some other cases can take years. This can develop frustration not only to the physicians but also to the patients as pain can create obstacles for their daily activities and it can turn into chronic pain (Othman and Ragab, 2012).

Heel pain is one of the most common foot and ankle disorder and plantar fasciitis (PF) is the most common heel pain to be complained about. Plantar fasciitis accounts for $15 \%$ of all adult foot complains that requiring professional care and it is prevalent in both athletes and non - athletic population. It is estimated that it affects as much as $10 \%$ of the population over the course of their lifetime. In a study stated that $83 \%$ of patients seen with PF were active working adults raging from twenty - five to sixty - four years of age (Scher D. et al, 2009). There is no data can be found about the prevalence of plantar fasciitis in Indonesia.

Obesity present in up to $70 \%$ of patient with plantar fasciitis, there is a strong association between body mass index (BMI) and plantar fasciitis in nonathletic individual. In assembly-line workers, risk factors for plantar fasciitis included time spent standing on hard surfaces, time spent walking, sitting, number of times jumping in and out of vehicles (for the truck/forklift drivers). Some reports suggest that that excessive pronation of the foot can be the risk factor for plantar fasciitis other factors such as biomechanical abnormalities in the foot such as a tight, pes cavus and pes planus, inadequate footwear and degenerative changes can also lead to PF (Cutts S. et al, 2012).

There are many debate among physicians about prolonged standing as the factor of PF. Prolonged standing is often cited as a causative factor for heel pain based on the theory that prolonged 
http://journalunair.ac.id/journal-of-orthopaedic-and-traumatology-surabaya-media-104.html

tensile loading of the plantar fascia exposes individuals to the condition. However, no previous study has adequately define prolonged standing. Even on the information obtained from the medical website on the Internet, prolonged standing is stated as one of the risk factor that causing plantar fasciitis.

According to a study conducted by Werner $\mathrm{R}$ et al in 2009, it concluded that increase time spent on standing and time spent walking, and increase in the number of time getting in and out of vehicles increase the risk of getting plantar fasciitis. This believe that prolonged standing can lead to plantar fasciitis has been cited by many journal, another example of journal that stated this is a journal by Tae Im Yi et al (2011) which quoted that occupations that involve long periods of standing can increase the risk of PF. However, there are many debates among physicians on this issue. In a test conducted by Irving D et al in 2007, it tried to prove that there is no association found between PF and average times spend on walking, standing, standing and other lower limb stress occupation and many other journal cited this theory.

This uncertainty can lead confusion to publics. The purpose of this study is to find out whether or not the PF patients that are found in the clinic has prolonged standing as their risk factor.

\section{METHODS}

This research, based on the location and action, it is categorized observational analytic study, with the purpose analyzing the correlation between prolonged standing and the symptoms of plantar fasciitis. The design of this study is a cross sectional study to find out the correlation between two variables.

This study involved all the factory workers from a factory, PT. X in Rungkut, Surabaya. Collecting data of the subjects was conducted for two months from October 2016 - November 2016.

\section{RESULTS AND DISCUSSION}

There are 73 workers in total. 35 of them did not fulfill the inclusion criteria. From those 35 subjects, 1 of them is obese, 22 are at the age of below 30 years old and 12 of them are women who work at the office. Due to the uneven distribution of male and female workers at this company, it is decided that only the male workers are used for this research, thus only 38 subjects that fulfill the inclusive criteria. All the research subject 
http://journalunair.ac.id/journal-of-orthopaedic-and-traumatology-surabaya-media-104.html

demography such as age, body weight and height were noted.

Table 1. Overview Characteristic of the Subjects

\begin{tabular}{|c|c|c|c|}
\hline \multirow[t]{2}{*}{ Variable } & \multicolumn{3}{|c|}{$\mathbf{N}(38)$} \\
\hline & Mean $( \pm$ SD $)$ & Minimum & Maximum \\
\hline $\begin{array}{c}\text { Age } \\
\text { (years) }\end{array}$ & $38.8( \pm 5.804)$ & 30 & 48 \\
\hline $\begin{array}{c}{ }^{1} \mathbf{B M I} \\
\left(\mathbf{K g} / \mathbf{m}^{2}\right)\end{array}$ & $19.4( \pm 2.021)$ & 14.8 & 23.8 \\
\hline $\begin{array}{c}\text { Standing } \\
\text { Duration } \\
\text { (hours) }\end{array}$ & $4.68( \pm 2.767)$ & 1 & 8 \\
\hline
\end{tabular}

${ }^{1}$ BMI : Body Mass Index (WHO asian standard); Underweight: 18.5, Normal: 18.5-22.9, Overweight 23 and above, Obese : 25.0-29.9

The table above shows the mean age of the subjects is $38.8 \pm 5.804$. The youngest subject is 30 years old while the oldest is 48 years old. The mean BMI of the subjects is $19.4 \pm 2.386$. The lowest BMI of the subject is 14.8 while the highest BMI is 23.8. The mean for Standing duration of the subjects is 4.68 \pm 2.767 . The shortest standing duration of the subject is 1 hour while the longest standing duration of the subject is 8 hours. However, for the test the standing duration is categorized as prolonged 6 hours or more and short 5 hours and less.

The diagnosis of plantar fasciitis is usually clinical and rarely needs to be investigated further as it has its classic presentation. The classic symptom of plantar fasciitis is pain in the medial side of the heel. Patients will complaint about the pain to be particularly bad with the first few steps taken on rising in the morning or it is most noticeable with initial steps after a period of inactivity and usually lessens with increasing level of activity during the day, but will tend to worsen toward the end of the day after an extended refrain from weight-bearing activity. Diagnostic imaging is rarely indicated for initial evaluation and treatment, but may be helpful in certain cases to rule out other causes of heel pain.

\begin{tabular}{lcc}
\hline \multicolumn{1}{c}{ Symptoms } & Total & Percentage (\%) \\
\hline Painful Morning Step & 3 & 7.9 \\
\hline Painful after inactivity & 4 & 10.5 \\
\hline $\begin{array}{l}\text { Pain while long } \\
\text { weight-bearing }\end{array}$ & 14 & 36.8 \\
\hline
\end{tabular}

(Tahiririan et al, 2012).

Table 2. Symptoms Characteristic The table above shows the response of the subjects to the symptoms of heel pain. One subject may have one or more symptoms and there are subjects who did not respond to these symptoms. The symptoms are painful morning step, painful after in activity and pain with long weight bearing. The total subjects that response to the symptoms are $3(7.9 \%), 4$ 
http://journalunair.ac.id/journal-of-orthopaedic-and-traumatology-surabaya-media-104.html

$(10.5 \%)$, and $14(36.8 \%)$ respectively.

Pain while long weight-bearing has the

\begin{tabular}{lcc}
\hline $\begin{array}{c}\text { Physical } \\
\text { Examination }\end{array}$ & Total & Percentage (\%) \\
\hline Painful on palpation & 8 & 21.1 \\
\hline $\begin{array}{l}\text { Windless test } \\
\text { positive }\end{array}$ & 3 & 7.9 \\
\hline $\begin{array}{l}\text { Passive dorsiflexion } \\
\text { (ROM) }\end{array}$ & 3 & 7.9 \\
\hline
\end{tabular}

highest subjects.

Table 3. Physical Examination

The table above shows the response of the subjects to the physical examination of heel pain. One subject may respond to one or more physical examination and there are subjects who did not respond to any of these exam. The examination is pain on palpation, windlass test positive and Passive Dorsiflexion. The total subjects that response to the examinations are $8(21.1 \%), 3(7.9 \%)$, and

\begin{tabular}{lcc}
\hline \multicolumn{3}{c}{ Plantar Fasciitis } \\
\hline & N & Percentage (\%) \\
\hline Diagnosed & 3 & 7.9 \\
\hline Non-Diagnosed & 35 & 92.1 \\
\hline Total & 38 & 100 \\
\hline
\end{tabular}

$3(7.9 \%)$ respectively.

Table 4. Diagnose of Plantar Fasciitis The table above shows the number of subjects that were diagnosed with plantar fasciitis. It shows that the number of subjects that have been diagnosed were

\begin{tabular}{|c|c|c|c|c|}
\hline & \multicolumn{2}{|c|}{ Plantar Fasciitis } & $\begin{array}{c}\mathrm{X}^{2} \\
\text { Fisher's } \\
\text { Exact } \\
\text { test }\end{array}$ \\
\hline & & $\begin{array}{c}\text { Diagnosed } \\
(\%)\end{array}$ & $\begin{array}{c}\text { Not } \\
\text { Diagnosed } \\
(\%)\end{array}$ & \multirow{4}{*}{0.249} \\
\hline \multirow{2}{*}{$\begin{array}{l}\text { Standing } \\
\text { category }\end{array}$} & $\begin{array}{c}\text { Pro- } \\
\text { longed }\end{array}$ & $\begin{array}{c}3 \\
(13.6 \%)\end{array}$ & $\begin{array}{c}19 \\
(86.4 \%)\end{array}$ & \\
\hline & Short & $\begin{array}{c}0 \\
(0.00 \%)\end{array}$ & $\begin{array}{c}16 \\
(100 \%)\end{array}$ & \\
\hline Total & & $\begin{array}{c}3 \\
(7.9 \%)\end{array}$ & $\begin{array}{c}35 \\
(92.1 \%)\end{array}$ & \\
\hline
\end{tabular}

3 and the others have not been diagnosed.

Table 5. Correlation between standing hour and Plantar Fasciitis diagnose

The table above shows the correlation between standing category: Prolonged and short with the diagnose of plantar fasciitis. The test is using chisquare and the value of $p$ is using fisher's exact test because the number of sample is too small. The $\mathrm{p}$ value is 0.249 which is not significant as it $>0.05$ which means there is no correlation between the standing category and the plantar fasciitis diagnose.

Normality test is used to find out 
http://journalunair.ac.id/journal-of-orthopaedic-and-traumatology-surabaya-media-104.html

whether or not the distribution of the sample is normal or abnormal. For this case Shapiro-wilk is used as the number of sample is $<50$ subjects. In this case the test is used to test the normality of age and BMI. The results for the normality test are $\mathrm{p}=0.012$ for age and $\mathrm{p}=0.351$ for BMI. As the value of $\mathrm{p}<0.05$ for age, it means that the distribution is not normal. Meanwhile the BMI value of $\mathrm{p}>0.05$ means the distribution is normal.

\section{CONCLUSION}

The standard used in RSUD Dr. Soetomo for diagnosing plantar fasciitis (PF) are; symptoms of medial plantar heel pain after a long inactivity, weight-bearing activity, pain on palpation and in chronic cases limping gait may be observed. While the Orthopaedic Section of the American Physical Therapy Association (AFTA) guidelines, recommended that the following criteria should be used for the diagnose of heel pain and PF; pain on palpation of the proximal insertion of the plantar fascia, limited ankle dorsiflexion range of motion (ROM), abnormal foot postur index score, positive windlass test, negative tarsal tunnel test. According to research conducted by Hossain et all in 2011, windlass test is specific for plantar fasciopathy. on the current practice in UK in diagnosing plantar fasciitis suggested that in UK the three most common diagnose used is pain on palpation, pain on first step in the morning and pain on plantar fascia stretch. However, there is no standarized method for diagnosing plantar fasciitis (Rob Grieve, Shea Palmer 2016).

The subjects that are diagnosed with plantar fasciitis according to this study are three subjects. Standing hours is divided into two types, prolonged and short. According to a study by McCulloch et al in 2012, prolonged standing is 6 hours and more standing. The test used find the correlation between stanidng and plantar fasciitis is chi-square. The $\mathrm{p}$ results is 0.249 which means there is no correlation. This is contary with a study which stated that PF is relatively common in manufacturing setting and work station that reduce the $\%$ of time walking or standing on hard surface may lower the risk of PF (Anthony Luke, 2015). However in study conducted by Damien Irving et al in 2010, using the occupational rating scale, shows that there is a low evidence between prolonged standing and PF, however, no previous study has adequately defined prolonged standing (Damien BI, et al, 2010). 
http://journalunair.ac.id/journal-of-orthopaedic-and-traumatology-surabaya-media-104.html

\section{SUGGESTION}

Research can be done on population based with larger number of subjects. Due to limitation from the researcher, other measure can be used to determine the definition of prolonged standing, other risk factor such as biomechanical abnormality. Next study may also consider the measurement to determine the footwear quality.

\section{REFERENCES}

Ahmed Othman, Ragab E., et al, 2012, "Platelet Rich Plasma For Treatment Of Chronic Plantar Fasciitis", Springer Link, Accessed on $16^{\text {th }}$ January 2016 http://link.springer.com/article/10.1007 /s00402-012-1505-8\#/page-1

Anthony Luke, 2015," Physical Examination on ankle and foot"., University of California, available for http://orthosurg.ucsf.edu/patientcare/divisions/sportsmedicine/conditions/physicalexamination-info/ankle-physicalexamination/ (24 January 2017).

Cutts S., Obi N., Pasapula C., Chan W., 2012, "Plantar Fasciitis" RCS, Accessed on $20^{\text {th }}$ January 2016 http://www.ncbi.nlm.nih.gov/pmc/articl es/PMC3954277/

Damien B, Caalghan J, 2010 "Standing on a decline surface reduces transient prolonged standing induced low back pain development", Elsevier. http://www.sciencedirect.com/science/a rticle/pii/S000368701630059X

Irving D., Cook J., et al, 2007, "Obesity and Pronated Foot Type May Increase The Risk of Chronic Plantar Pain",
Biomed Central. Accessed on $13^{\text {th }}$ January 2016.

Mc Culloch J,2012, “ Health Risk Associated with Prolonged Standing”, NCBI, available for https://www.ncbi.nlm.nih.gov/pubmed/ ?term=ploronged+standing + McChulloc hs (23 January 2017).

Rob Grieve, Shea Palmer,2016." Physiotherapy for Plantar Fasciitis: a UK-Wide Survey of Current Practice", Elsevier. Available for http://www.sciencedirect.com/science/a rticle/pii/S1877132711000297 January 2017)

Scher D., Belmont Jr., Bear R., et al, 2009, " The Incedence of Plantar Fasciitis in The United State Military", The Journal of Bone and Joint Surgery, Accesed on $20^{\text {th }}$ January 2015

Tae Im Yi, Ga Eun Lee, In Seok Seo, et al, 2011, "Clinical Characteristics of The Cause of Plantar Heel Pain", Annals of Rehabilitation Medicine,

Tahiririan M., Motififard M., et al, 2012, "Plantar Fasciitis", NCIB, Accessed on $15^{\text {th }} \quad$ January 2016 http://www.ncbi.nlm.nih.gov/pmc/articl es/PMC3687890/

Werner R., Gell N., et al, 2009, "Risk Factor For Plantar Fasciitis Among Assembly Plant Workes", Elsevier, Accessed on $15^{\text {th }}$ January 2016 http://www.sciencedirect.com/science/a rticle/pii/S0003687008000720 